\title{
Research on the Competency in the View of the Counselors' Occupational Capability Standard in Colleges and Universities*
}

\author{
Guang Li \\ School of Education \\ Baoshan University \\ Baoshan, China 678000
}

\begin{abstract}
Based on the perspective of the Occupational Capability Standard of college counselors, this paper studies the competency of college counselors in Yunnan province by using the Behavioral Event Interview, to provide scientific theoretical and practical basis for counselor's Occupational Capability Standard. It is found that the factors of the competency of college counselors in Yunnan province include interpersonal understanding, communication and coordination, knowledge and skills, initiative, self-confidence, caring about others, learning and development, achievement orientation, responsibility, analytical thinking, organizational identity; According to the frequency, the average score and the highest points of the competency factors, it can be divided into excellent groups and general groups, and the competency factors are not affected by the length of the interview text; the frequency, the average score and the highest points of the competency factors may increase with the increasing of the interview text, while the impact of the frequency index is relatively stable.
\end{abstract}

Keywords-occupational capability standard; behavioral event interview; college counselor; competency

\section{INTRODUCTION}

David McClelland ${ }^{1}$, a professor at Harvard University, presented the concept of competency in 1973, referring to the deep-seated characteristics of individuals that can distinguish outstanding performers from ordinary people at work, including knowledge, behavioral skills, motivation, characteristics, self-image, attitudes, values and other individual characteristics that can be measured and can significantly distinguish the excellent performance from general performance. From the point of view of ability, attitude and personality characteristics, Bray and others summed up 25

*Fund Project: The phased achievements of the research project of college students' ideological and political education in Yunnan province "Research on the Competency in the View of the Counselors' Occupational Capability Standard in Colleges and Universities- Taking Yunnan Province as an Example" (Item No.: JZ100018); Special task project of Humanities and Social Sciences in Ministry of Education (ideological and political work) "A Study on the Path of Promoting the Occupational Capability of Counselors in Colleges and Universities Based on the Excellent Competency Model" (subject number: 16JDSZ2054) fund..

1 McClelland, D.C. Testing for competence Rather Than for "Intelligence"[J].Journal of American Psychologist, 1973:1-14. important factors impacting the college counselors achievement. After did some research, Yang Jiping and $\mathrm{Gu}$ Qian concluded 16 competencies. Peng Qinghong built the quality of college counselors, including professional knowledge, management skills, personal ideology and politics. Hao Yingjie put forward that to build the competency model of college counselor should be based on ability, quality, and personality charm and so on.

In 2014, the Ministry of Education issued the document "Counselors' Occupational Capability Standard in Colleges and Universities (Interim)", which put forward more specific requirements to the college counselor's occupational capability standards. The document "Counselors' Occupational Capability Standard in Colleges and Universities (Interim)" shows the high degree of concern of the college counselors' competency, the hope to build an ideological and political education team with high-quality, high-standards and high-performance, in order to provide personnel protection for the college ideological and political education work.

\section{RESEARCH METHODS AND STEPS}

\section{A. Examinee}

According to whether obtain the school level and above "excellent counselor", "counselor annual figures" or not, they can be divided into excellent group and general group. A total of 30 counselors from Yunnan Normal University, Kunming University of Science and Technology, Kunming University, Yunnan University of Finance and Economics, Yunnan Nationalities University, Baoshan University and Yunnan Normal University of Science and Technology and so on were selected to participate in the interview with the convenience sampling method. The school samples involved different levels, area, category, etc., are representative. Among them, there are 13 males and 17 females. According to the grouping method, 15 people are divided into excellent group, which are 8 males and 7 females, and 15 people are divided into general group, which are 5 males and 10 females. 


\section{B. Research Methods}

In the competency research, the most approved method is mainly the behavior event interview. It mainly selects the incumbents in target position to be the interviewee, through a detailed review of the examinees' most typical characteristics (the most successful and most failed) events (usually three for each) during the job, by using the theme analysis to find out the examinees' capacity quality in the event, then by comparing the differences between the excellent group and the general group to extract the competency to meet the target position.

\section{Research Steps}

1. Terms gathering create the code dictionary of counselors' competency. Through the preparation of open questionnaires, adopt the 360-degree method to collect the job competency keywords, including the school leadership charging students, student office, the deputy secretary, students, counselors and related functional departments of college (departments). Invite the examinees to list 10-15 terms that can summarize the counselor's competency. According to Professor Hao Yingjie's classification of the competency structure of college counselors, the collected 96 terms can be sorted and classified from the professional knowledge and skills, general ability, core competence, occupation self-restraint and personality charm. The results are shown in "Table I".

\section{TABLE I $\quad$ TERMS OF COUNSELORS COMPETENCY}

\begin{tabular}{|c|c|}
\hline Dimension & Terms \\
\hline $\begin{array}{l}\text { Professional } \\
\text { knowledge } \\
\text { and skills }\end{array}$ & $\begin{array}{l}\text { Psychological guidance ability, knowledge of psychology, } \\
\text { knowledge of ideological and political education, knowledge } \\
\text { of politics, knowledge of office, knowledge of policy and } \\
\text { regulations, knowledge of sociology, knowledge of } \\
\text { education, knowledge of party group, professional } \\
\text { knowledge, legal knowledge, management knowledge, } \\
\text { humanistic knowledge, documentary knowledge ,Career } \\
\text { Guidance }\end{array}$ \\
\hline $\begin{array}{l}\text { General } \\
\text { ability }\end{array}$ & $\begin{array}{l}\text { Expression ability, coordination ability, organizational } \\
\text { ability, innovation ability, observation ability, guiding } \\
\text { ability, introspective ability, work ability, leadership ability, } \\
\text { management ability, analytical ability, strategic management } \\
\text { ability, decision-making ability, competitive spirit, foresee } \\
\text { ability, analytical thinking, conceptual thinking, focus on } \\
\text { quality, flexibility, motivation, team leadership, } \\
\text { decisiveness, meticulous, tenacity, self-control, insight, } \\
\text { tolerance, scientific research ability, social experience, work } \\
\text { experience, willpower, information collection, information } \\
\text { processing, plan execution }\end{array}$ \\
\hline $\begin{array}{l}\text { Core } \\
\text { competence }\end{array}$ & $\begin{array}{l}\text { Communication ability, contingency ability, care for } \\
\text { students, understand for students, respect for students, } \\
\text { learning ability, problem solving ability, sense of } \\
\text { cooperation, sense of service, cultivate students, concern for } \\
\text { students, responsibility }\end{array}$ \\
\hline $\begin{array}{l}\text { Occupation } \\
\text { self-restraint }\end{array}$ & $\begin{array}{l}\text { Organizational identification, ideological and moral } \\
\text { cultivation, principle, initiative, enthusiasm, professional } \\
\text { quality, scientific and cultural quality, physical quality, } \\
\text { psychological quality, work passion, listening ability, } \\
\text { sensitivity, moral quality, overall consciousness, dedication } \\
\text { spirit, impartial treatment, gratitude consciousness, patience, } \\
\text { democratic consciousness, right consciousness, self - } \\
\text { discipline }\end{array}$ \\
\hline $\begin{array}{l}\text { Personality } \\
\text { charm }\end{array}$ & $\begin{array}{l}\text { Personal charm, affinity, self-evaluation, self-confidence, } \\
\text { self-reflection, optimism, agreeableness, make self an } \\
\text { example, approachable, sincere, prestige, courage, assertive, } \\
\text { honest }\end{array}$ \\
\hline
\end{tabular}

Invite the leadership of the Student Affairs Office (Department,) leadership of the Youth League Committee, chairman or secretary (student) of League Work, Master of Psychology, Master of Ideological and Political Education, respectively one of each, to classify the college counselor competency terms back to back, then select the terms recognized by at least three of them to get the 42 terms "Table II".

\section{TABLE II. COUNSELOR COMPETENCY TERMS}

\begin{tabular}{|c|c|}
\hline Dimension & Terms \\
\hline $\begin{array}{l}\text { Professional } \\
\text { knowledge }\end{array}$ & $\begin{array}{l}\text { Knowledge and skills (including professional knowledge } \\
\text { and skills, comprehensive knowledge and skills) }\end{array}$ \\
\hline $\begin{array}{l}\text { General } \\
\text { ability }\end{array}$ & $\begin{array}{l}\text { Achievement orientation, initiative, information } \\
\text { collection, authority and influence, relationship building, } \\
\text { self-control, flexibility, authority, teamwork, team } \\
\text { leadership, analytical thinking, conceptual thinking, } \\
\text { awareness, innovation ability, encouragement, } \\
\text { communication and coordination, plan implementation, } \\
\text { interpersonal communication, flexibility and adaptation, } \\
\text { action, organization, analysis and judgment, execution, } \\
\text { guidance and monitoring }\end{array}$ \\
\hline $\begin{array}{l}\text { Core } \\
\text { competence }\end{array}$ & $\begin{array}{l}\text { Interpersonal understanding, sense of responsibility, } \\
\text { cultivating others, caring others, learning development, } \\
\text { dedication, people-oriented }\end{array}$ \\
\hline $\begin{array}{l}\text { Occupation } \\
\text { self-restraint }\end{array}$ & $\begin{array}{l}\text { Overall conception, self - discipline, organizational } \\
\text { identity, experience openness, attention to detail }\end{array}$ \\
\hline $\begin{array}{l}\text { Personality } \\
\text { charm }\end{array}$ & $\begin{array}{l}\text { Self-confidence, introspection, integrity, empathy, } \\
\text { charisma }\end{array}$ \\
\hline
\end{tabular}

Construct the Competency Code Dictionary of college instructors based on the determined terms. Each term consists of name, definition, level and behavioral description. Each term is accompanied by six levels brief behavioral descriptions. The level represents the intensity or complexity of the behavioral performance. Different levels of behavioral description are mainly representative behavioral performance in counselor's work.

2. Carry out the behavioral event interviews. According to the interview outline, appoint interviews by face-to-face or telephone, examinees should be stated the secrecy before the interviews. The interview should use the double-blind way to avoid hints and expected effects. The specific approach is to first interview, and then to ask for filling the basic information of the examinees after the interview. According to whether obtain the school level and above "excellent counselor", "counselor annual figures" or not, they can be divided into excellent group and general group to record as text.

3. Record the interview material. After the behavioral event interview, the interview material will be collated and recorded as the electronic version material by the leader of each research group.

4. Competency code. On the basis of the competency dictionary, the theme and the behavior level of the interview material were excavated by theme analysis and content analysis In order to facilitate the discussion, this work is completed mainly by two members of the nearest task group. Before the encoding, these two members, back to back, are required to independently perform the theme analysis, to determine the 
topic name, behavior level division and so on after reading the text material and being familiar with the competency dictionary At last, these two people compare, discuss and supplement their encoding, to determine the coding results with the highest consistency. In this step, a double-blind design is still used, that is, the coder does not know the grouping situation of the examinees.

5. Data collation analysis. Use SPSS11.5 data software, according to the indicators of behavior event interview and the relevant indicators of competency code, to sort statistics. The indicators of the behavioral event interview include the time of interview, the number of words, the frequency of competency at different levels, and the indicators of competency include the level score, the frequency, the average level score and the highest level score and so on. Do the statistical analysis according to the difference of competency factors in the excellent group and the general group.

6. Study on the counselor competency. Extract the competency of college counselors in Yunnan province according to the data analysis to.

\section{RESULTS AND ANALYSIS}

\section{A. Analysis on the Length of Interview Text}

According to the statistical analysis on the behavioral event interview text, the average length of the interview text of the excellent group is 5778 words $(\mathrm{SD}=1097)$, and the average interview length of general group is 4675 words $(\mathrm{SD}=1280)$. The $\mathrm{T}$ test result is $\mathrm{t}=3.08(\mathrm{p}>0.05)$, indicating that there was no significant difference in the length of the interview between the excellent group and the general group "Table III", that is, the length of the text of the interview would not affect the differences in competency between the two groups.

TABLE III. T TEST OF THE LENGTH OF INTERVIEW TEXT

\begin{tabular}{lccccc}
\hline \multicolumn{1}{c}{ Grouping } & $\mathbf{N}$ & $\mathbf{M}$ & SD & t & P \\
\hline Excellent group & 15 & 5778.33 & 1096.54 & 3.08 & 0.06 \\
General group & 15 & 4675.41 & 1280.45 & & \\
\hline
\end{tabular}

Then analyse the correlation between the length of the text and the frequency, average score and the highest score of competency elements, the relevant statistical results in "Table IV".

From the results, it can be seen that the correlation between the length and frequency of the text is significant in interpersonal comprehension, self-confidence, and caring others. In the interpersonal understanding, self-confidence, sense of responsibility, and organizational identity, the correlation between the length of the text and the average score are significant; in the interpersonal understanding, selfconfidence, analytical thinking, and knowledge and skills, the correlation between the highest score and the length is significant. These indicate that with the length of the interview text increasing, the frequency, average score and the highest score of competency will increase, and the impact of frequency indicator is smaller, which is consistent with most of the existing research results.

TABLE IV. THE CORRELATION BETWEEN THE LENGTH OF THE TEXT AND THE FREQUENCY, AVERAGE SCORE AND THE HIGHEST SCORE

\begin{tabular}{|c|c|c|c|}
\hline Competency & $\begin{array}{l}\text { The length of } \\
\text { the text and the } \\
\text { frequency }\end{array}$ & $\begin{array}{l}\text { The average } \\
\text { score and the } \\
\text { length of text }\end{array}$ & $\begin{array}{c}\text { The highest } \\
\text { score and the } \\
\text { length of the } \\
\text { text }\end{array}$ \\
\hline $\begin{array}{l}\text { Interpersonal } \\
\text { understanding }\end{array}$ & $0.45^{* *}$ & $0.66^{*}$ & $0.47 *$ \\
\hline $\begin{array}{l}\text { Achievement } \\
\text { orientation }\end{array}$ & 0.23 & 0.31 & 0.18 \\
\hline Initiative & 0.33 & 0.28 & 0.21 \\
\hline Self-control & -0.09 & -0.16 & -0.12 \\
\hline Self-confidence & $0.20 *$ & $0.22 *$ & $0.35^{*}$ \\
\hline $\begin{array}{l}\text { Sense of } \\
\text { responsibility }\end{array}$ & 0.31 & $0.38 *$ & 0.41 \\
\hline Cultivating others & 0.26 & 0.34 & 0.20 \\
\hline Team leadership & -0.15 & 0.21 & 0.36 \\
\hline Analytical thinking & 0.26 & 0.27 & $0.45^{*}$ \\
\hline Conceptual thinking & 0.27 & 0.29 & 0.15 \\
\hline Caring others & $0.18^{*}$ & 0.24 & 0.19 \\
\hline $\begin{array}{l}\text { Learning } \\
\text { development }\end{array}$ & 0.46 & 0.41 & 0.47 \\
\hline $\begin{array}{l}\text { Communication and } \\
\text { coordination }\end{array}$ & 0.23 & 0.35 & 0.21 \\
\hline Introspection & -0.10 & -0.06 & -0.08 \\
\hline $\begin{array}{l}\text { Organizational } \\
\text { identity }\end{array}$ & 0.44 & $0.29 *$ & 0.32 \\
\hline Empathy & 0.28 & 0.18 & 0.23 \\
\hline $\begin{array}{l}\text { Knowledge and } \\
\text { skills }\end{array}$ & 0.37 & 0.31 & $0.34 *$ \\
\hline
\end{tabular}

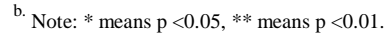

\section{B. Competency Structure}

Combined with Spencer's research conclusion, when constructing the competency model, you can search in accordance with the frequency, the average score or the highest score of the competency factor. In the study, the statistics of the three indicators were analyzed comprehensively. The results are shown in "Table V".

In accordance with the statistics result, check the difference of the competency in frequency, average score and the highest score, which shows that there are 8 significant differences in frequency indicator, 7 significant differences in average score indicator, and 6 significant differences in the highest score indicator. This illustrates that the competency no matter with the frequency indicator, average score indicator or the highest score indicator can be divided into excellent group and general group. And there is repeatability in the competency factors which are discovered based on the frequency, average score and the highest score. Except it only shows once in the achievement orientation, sense of responsibility, analytical thinking and organizational identity, it shows more than twice in others. 
The T Test of Frequency, Average SCore AND the Highest SCore IN DifFerent Groups

\begin{tabular}{|c|c|c|c|c|c|c|c|c|c|}
\hline \multirow{2}{*}{ Competency } & \multicolumn{3}{|c|}{ Frequency } & \multicolumn{3}{|c|}{ Average score } & \multicolumn{3}{|c|}{ The highest score } \\
\hline & $\begin{array}{l}\text { Excellent } \\
\text { group }\end{array}$ & $\begin{array}{l}\text { General } \\
\text { group }\end{array}$ & $T$ & $\begin{array}{l}\text { Excellent } \\
\text { group }\end{array}$ & $\begin{array}{l}\text { General } \\
\text { group }\end{array}$ & $T$ & $\begin{array}{l}\text { Excellent } \\
\text { group }\end{array}$ & $\begin{array}{l}\text { General } \\
\text { group }\end{array}$ & $T$ \\
\hline $\begin{array}{l}\text { Interpersonal } \\
\text { understanding }\end{array}$ & 3.01 & 2.12 & $2.25 * *$ & 2.97 & 2.16 & $1.89 * *$ & 5.11 & 4.32 & $2.01 *$ \\
\hline $\begin{array}{l}\text { Achievement } \\
\text { orientation }\end{array}$ & 1.65 & 1.46 & 0.59 & 1.72 & 1.69 & 0.77 & 1.25 & 1.94 & $1.55 * *$ \\
\hline Initiative & 1.76 & 1.52 & $1.12^{* *}$ & 2.10 & 1.88 & $1.32 * *$ & 1.02 & 1.61 & 0.88 \\
\hline Self-control & 2.17 & 1.49 & 0.15 & 1.91 & 1.38 & 0.26 & 1.71 & 1.51 & 1.09 \\
\hline Self-confidence & 4.12 & 3.56 & $0.78 * *$ & 3.28 & 2,19 & 0.84 & 3.21 & 2.55 & $0.54 *$ \\
\hline Sense of responsibility & 1.88 & 1.21 & $0.69^{*}$ & 1.35 & 1.61 & 0.56 & 0.91 & 1.24 & 1.00 \\
\hline Cultivating others & 0.53 & 0.39 & 0.66 & 1.22 & 0.79 & 0.71 & 1.48 & 0.99 & 0.51 \\
\hline Team leadership & 1.25 & 1.36 & 0.79 & 1.52 & 1.19 & 1.77 & 1.95 & 1.34 & 1.21 \\
\hline Analytical thinking & 1.95 & 1.82 & $0.51^{*}$ & 1.61 & 1.18 & 0.66 & 1.51 & 1.11 & 1.02 \\
\hline Conceptual thinking & 0.03 & 0.39 & 0.29 & 0.72 & 0.71 & 0.51 & 1.08 & 0.49 & 0.61 \\
\hline Caring others & 0.53 & 0.41 & $1.76^{*}$ & 1.61 & 1.48 & $0.86^{*}$ & 1.51 & 1.07 & 1.42 \\
\hline Learning development & 2.57 & 2.49 & 1.15 & 1.71 & 1.68 & $1.24^{*}$ & 2.18 & 2.40 & $1.28 *$ \\
\hline $\begin{array}{l}\text { Communication and } \\
\text { coordination }\end{array}$ & 1.84 & 1.62 & $1.33 * *$ & 2.19 & 0.97 & $1.67 * *$ & 1.32 & 1.67 & $1.58 * *$ \\
\hline Introspection & 0.25 & 0.36 & 0.72 & 0.52 & 1.29 & 1.17 & 0.95 & 1.64 & 1.00 \\
\hline Organizational identity & 1.57 & 2.19 & 2.15 & 2.31 & 1.18 & $2.14^{*}$ & 1.83 & 1.52 & 1.14 \\
\hline Empathy & 1.65 & 1.16 & 0.49 & 1.22 & 1.10 & 1.72 & 0.95 & 1.24 & 0.21 \\
\hline Knowledge and skills & 1.81 & 1.48 & $0.98 * *$ & 1.25 & 1.09 & $1.12 * *$ & 1.69 & 1.58 & $1.08 * *$ \\
\hline
\end{tabular}

In this study, as these three indicators: frequency, average score and the highest score are analyzed in the same time, all the competency with significant difference should considered as a model when observing the counselors' competency structure. Of which, all the 3 indicators of interpersonal understanding, communication and coordination and knowledge and skills are significantly different; there 2 indicators of initiative, Self-confidence, caring others and learning development are significantly different; there 1 indicator of achievement orientation, sense of responsibility, analytical thinking and organizational identity is significantly different, a total of 11 factors are considered in the counselors' competency structure.

\section{Differential Analysis of Competency}

Use difference compare method to perform statistic analysis on the competency frequency in excellent group and general group, the results are shown in "Table VI".

TABLE VI. DIFFERENTIAL ANALYSIS OF COMPETENCY

\begin{tabular}{cccccc}
\hline Grouping & $\mathbf{N}$ & $\mathbf{M}$ & SD & $\mathbf{t}$ & $\mathbf{P}$ \\
\hline $\begin{array}{c}\text { Excellent } \\
\text { group }\end{array}$ & 15 & 35.35 & 6.23 & 6.35 & 0.00 \\
$\begin{array}{c}\text { General } \\
\text { group }\end{array}$ & 15 & 28.46 & 7.53 & & \\
\hline
\end{tabular}

The results show that the competency frequency indicators in excellent group $(\mathrm{M}=35, \mathrm{SD}=6)$ are higher than that in general group $(\mathrm{M}=28, \mathrm{SD}=8)$.

\section{Testing Reliability and Validity}

The reliability test is mainly checked from the consistency of the classification. In the study, it is explained by using the number of the same classifications that the scorers sort out the same interview text material as the percentage of the total number of codes. The formula is: $\mathrm{CA}=(2 \times \mathrm{T} 1 \cap \mathrm{T} 2) /(\mathrm{T} 1$ $\cup \mathrm{T} 2$ ), where $\mathrm{T} 1$ is the number of codes assigned by the scorer $\mathrm{A}, \mathrm{T} 2$ is the number of codes assigned by the scorer $\mathrm{B}$, and $\mathrm{T} 1 \cap \mathrm{T} 2$ indicates the number of the same core classifications scorers sort out, and $\mathrm{T} 1 \cup \mathrm{T} 2$ represents the sum of the number of codes. In the study, $\mathrm{T} 1=706, \mathrm{~T} 2=612$, $\mathrm{T} 1 \cap \mathrm{T} 2=599, \mathrm{CA}=90.9 \%$.

The validity test is interpreted according to the difference analysis of the frequency, the average scores and the highest scores of the competencies of different groups. As can be seen from the results in Table 4, the competencies of the excellent group are significantly higher than the general group. It shows that the competency of college counselors in Yunnan Province can distinguish the effective samples from the frequency, the average score and the highest score, and have good predictive power to the counselor's work.

\section{CONCLUSION}

(1) Use the behavioral event interview to explore the competency structure of the college counselor in Yunnan Province, it is found that all the frequency, the average score and the highest score of competency can distinguish the 
excellent group and the general group, and the competency factors are not affected by the length of the interview text.

(2) With the length of the interview text increasing, the frequency, average score and the highest score of competency will increase, and the impact of frequency indicator is relatively stable.

(3) According to the frequency, average score and the highest score of the competency factors, it is found that the competencies of college counselors in Yunnan province include knowledge and skills, achievement orientation, initiative, analytical thinking, communication and coordination, interpersonal understanding and sense of responsibility, care for others, learning development, organizational identity, selfconfidence.

(4) The competency structure of college counselors in Yunnan Province covers professional knowledge and skills, general ability, core competence, occupation self-restraint and personality charm. According to the onion model and the iceberg model of the competency, knowledge and skills, general ability, core competence belong to the outer layer, occupation self-restraint belongs to the middle layer, personality charm belongs to inner layer.

(5) According to the requirements of "Counselors' Occupational Capability Standard in Colleges and Universities (Interim)", Yunnan college counselors have the corresponding professional competency standards. Its competency structure meets the ability requirements of the document, with relevant theoretical knowledge. At the same time, the competency of college counselors in Yunnan Province also includes the organizational identity factor of occupation self-restraint dimension and the self-confidence factor of personality charm.

\section{DISCUSSION}

1) Research methods: About methods for researching the competency, the most approved method is mainly the behavior event interview, but its subjective in the research process is more obvious. In the interview, double-blind method is adopted in interview and encoding, and the subjectivity and arbitrariness are avoided to a great extent, which ensures the scientificity and objectivity of the research.

2) Analysis of competency factors: From the research point of view, there are differences when only explore one certain index, so the study synthesize three indicators of the integrated analysis. Among them, the impact of the interview text on the frequency indicator is relatively small, which is the same as McClelland' s research results. According to the research of Shi Kan and Zhong Lifeng and so on the competency23, the average score is not affected by the interviewee' $\mathrm{s}$ ability to express, with stability. The use of average score as a statistical indicator can maximally exclude the impact of language expression, to ensure a higher degree of reliability and validity.

${ }^{2}$ Shi Kan, Wang Jicheng,Li Chaoping.A Study on Competency Evaluation of Senior Management in Enterprises[J].Acta Psychologica Sinica, 2002, 34 (2).

${ }^{3}$ Zhong Lifeng, Shi Kan. Competency Model of Senior Management for Family Enterprises [J].. Acta Psychologica Sinica, 2004 (1)
The results of the study showed that there are 8 significant differences in frequency indicator, 7 significant differences in average score indicator, and 6 significant differences in the highest score indicator.

From the dimension number of competency model, the general rule of psychometrics "7 \pm 2 " is used as a reference, and the competency factor of college counselors is between 5 and 9 . If using the frequency, the average score or the highest score of competency factors as the analysis index, the number of competencies is 8,7 or 6 , which meets the reference conditions. The study analyzes the three indicators comprehensively; the final number of competency is 11 .

3) Reliability and validity test of competency model: Boyatzis, Burrus and other scholars found that the different encoders with training background used the highest score and frequency to encode, the consistency is between 0.74 and 0.80 . The reliability coefficient $\mathrm{CA}=90.9 \%$ obtained by using the classification consistency method in the study shows that the reliability is better, because in the encoding process, the encoders have in-depth study and discussion of the "Counselor Competency Dictionary", and encode in strict accordance with the rules.

Use the three competency model put forward by $\mathrm{Mc}$ Clelland: the same time cross-validity, the same time construct validity and predictive validity to inspect strategies. The competency model of counselors is verified by cross validity in the study. Use the difference analysis to inspect the excellent group and general group, and the results show that the competency of the excellent group is superior to the general group in the frequency, the average score and the highest score, which shows that the model has good predictive power.

4) To compare with Counselors' Occupational Capability Standard in Colleges and Universities (Interim): From the point of view of the document, the professional competency standard of the college counselor is divided into three levels: the primary, the intermediate and the senior, and the professional function, the work content, the capability requirement and the theoretical knowledge request are discussed in detail at each level.

"Counselors' Occupational Capability Standard in Colleges and Universities" comes from the ability requirements to the counselor's job competency, and his completion of the task, it is also the ability expectation to train counselor talents. And the competency is the prerequisite and basis for the counselor to perform the duties of the job. The knowledge and skills, self-confidence, caring others, learning development, organizational identity and other factors in the model are highly consistent with the purpose of the document, the requirements of the professional code. And according to the ability requirements of counselors in the document, interpersonal understanding, communication and coordination, initiative, achievement-oriented, sense of responsibility, analytical thinking and other factors have a clear description. It can be seen that Yunnan college counselors have reached the standard of professional competency and have the ability characteristics to engage in the work of counselors. At the same time, the model also involves the two dimensions of professionalism and personality charm, which correspond to 
the two competency characteristics of organizational identity and self-confidence. These two characteristics are the implicit layers in competency structure. From the point of view of the management practice of the counselor, the counselor post changes more frequent in the university, and the counselor is easy to shake with the future development due to the expectation of his work, his own position and so on, and even leave the counselor post, Thus, the two features in the competency structure are particularly important. The implicit layers of competency structure involves the most essential and intrinsic need of counselor's individual, it is difficult to change them, and the influence of external factors is relatively small. Its reflection in the "Counselors' Occupational Capability Standard in Colleges and Universities (Interim)" is not obvious enough; this is the considered standard which should be given the priority to in the future.

\section{CONCLUSION}

From the competency structure of college counselors in Yunnan Province, the characteristics of the various factors are in line with the relevant requirements of the professional competency standard. Based on this, to build the consoler talent training mode oriented by professional ability has a very important significance for improving the job competency of counselors, promoting the development of counselors 'professionalization, professionalism, expertization and improving the quality of students' work.

\section{REFERENCES}

[1] McClelland D C. Testing for competence Rather Than for"Intelligence"[J].Journal of American Psychologist,1973,1-14.

[2] BURKARD A, COLE D C, OTT Metal. Entry-level competencies of new student affairs professionals: adelphi study[J]. NASPA Journal, 2005,42(3).

[3] Notice of the Ministry of Education on Printing and Distributing the Criteria for the Counselors' Occupational Capability Standard in Colleges and Universities (Interim),http://www.gov.cn/xinwen/201404/14/content_2658616.htm.

[4] Lu Xiaohan.A Study on the Competence of College Instructors[D].Shanghai:Shanghai Normal University,2015(3),35.

[5] Zhong Lifeng,Shi Kan.Competency Model of Senior Management for Family Enterprises[J].Acta Psychologica Sinica,2004(1).

[6] Yang Jiping,Gu Qian.A Preliminary Study on the Competency of College Student Counselors[J].ShanxiJournal of Philosophy (Philosophy and Social Sciences),2004(6),56-58.

[7] Peng Qinghong.The Construction of Quality Structure Model of College Counselors[J].Research On Education Tsinghua University,2006(3),9094. 